\title{
Evaluation on Implementation Of Performance Management in Asuransi Jiwa Bersama (Ajb) Bumiputera 1912
}

\author{
Sri Nurchayati \\ HR Departement, AJB Bumiputera 1912. \\ sri.nurchayati@yahoo.com
}

\begin{abstract}
This study aimed to evaluate the implementation of performance management in AJB Bumiputera 1912. This study uses DEM (Discrepancy Evaluation Method) evaluation method. The components that were evaluated are the component of design, installation, implementation, and outcome. The methods used in this study is a questionnaire on 51 unit leader respondents at the headquarter and regional offices, the 150 employees of the central office, the interview method on 10 respondents, observation and study documentsmethod. The results of this study indicate that there is a gap between the actual conditions (Performance) with the condition that should be happened (Standard) on all four components that were analyzed. In conclusion, it is necessary to do some improvements to reduce the gap so that the actual conditions more closely the conditions that should be happened. The improvements that need to be done are alignment of the performance management design with the needs of company at this time, the need for commitment to change from the top down, implementation of reward and punishment continuously, and the need to support tools and technologies that were integrated, so the individual and team performance increased and imply to organization performance to be a leading position in life insurance industries in Indonesia.
\end{abstract}

Keyword: performance management, discrepancy evaluation model, discrepancy, transformation of human resource management.

\section{INTRODUCTION}

To improve the quality of HR in AJB Bumiputera 1912 to become the company's competitiveness, it is necessary to developtheCompetency-Based HR Management System that integrated so that it will improve the satisfaction and productivity of work, and provide the objectives assessment of performance evaluation process. Therefore, it is important to do research and evaluation on the implementation of performance management in AJB Bumiputera 1912, so it can picture whether the existing system is a valid and precise measuring tool and is already implemented properly to evaluate the performance of employees in AJB Bumiputera 1912.

According to Ivancevich (2007), There are three crucial elements needed by the organization to be effective, they are: (1) the mission and strategy; (2) the organizational structure; (3) management of human resources. Noe (2011) defines performance management as the process in which managers ensure that the output and activities of employees arealign with the organizational goals. Further said that performance management is the core to achieve competitive advantage.

Armstrong (2009) said performance management contribute to the achievement of cultural change and also integrated with the keys of the other HR activities, especially human resource management, talent management, learning \&development, and reward management. Performance management helps achieve horizontal integration and unification of HR practices that become connected and complementary and reinforce each other. As an important part of high-performance 
work systems, performance management systems contribute to the development of more effective work that determines the level of performance.

The results of the research that are relevant to this study are: 1) Ipsita C. Patranabis dan Sharmistha Banerjee entitled "Impact of emotional intelligence on performance of insurance marketers: a study of personnel in Indian Public sector; 2) Keyvan Farivar, Ali Tizroo, dan Farzad Sattari Ardabil entitled "Surveying the Relationship Between Role Definition and Performance Enhancement of Insurance Companies"e Sale Networks in Ardabil Province; 3) Hyondong Kim dan Kang Sungchoon entitled "Strategic HR functions and firm performance: The moderating effects of high-involvement work practices; 4) Suman Pathak dan Vibhuti Tripathi entitled "Sales Force Turnover: An Exploratory Study of the Indian Insurance Sector; 5) Venclová Kateřina, Šalková Andrea, Koláčková Gabriela entitled "Identification of Employee Performance Appraisal Methods in Agricultural Organizations; 6) Konrad Walser, Etienne Huber, André Meister entitled "Planning, budgeting and performance management at Swiss hospitals - Are Swiss hospitals at a crossroads - Will these medical specialist organisations in future develop into institutions with a business orientation?; 7) DU Jing-yi entitled "Staff performance appraisal based on data envelopment analysis (DEA); 8) S. Baloyi, C.C. van Waveren, \& K.-Y. Chan entitled "The Role of Supervisor Support in Predicting Employee Job Satisfaction From Their Perception of The Performance Management System: A Test of Competing Models in Engineering Environments"; 9) C Guido Alessandri, Michele Vecchione, John Tisak, entitled "The Utility of Positive Orientation in Predicting Job Performance and Organisational Citizenship Behaviors; 10) Zijiang Yang entitled "A two-stage DEA model to evaluate the overall performance of Canadian life and health insurance companies".

As well as human resource management activities in general, the Department of Human Resources in AJB Bumiputera 1912 at the end of every year do performance appraisal and the administration of employee performance evaluation results compiled from the results of performance assessment made by leaders of work units respectively. Based on the SK No. 22 / DIRPEL / 1994, there has been a change in the remuneration system, which was previously based on the period of the employment into the remuneration system based on the merit system. Merit system is a system of pay based on employee performance, so that the necessary tools to measure performance based on an assessment of the work performance is concerned.

Based on the SK No. 22 / DIRPEL / 1994, those involved in the management of employee performance in AJB Bumiputera 1912 are: (1) Structural Official, (2) Superior Assessor, and (3) Performance Assessment Committee. Assessment work is done on every July for observation period January to June, and assessment on every January for observation period January to December. The assessment of this employee "esperformance done in each work unit in the Head Office, Regional Offices and Branch Offices spread across Indonesia, and also for employees who are placed in subsidiaries that receive payroll from AJB Bumiputera 1912.

The assessment criteria for the employees in the central office and branch office employees are distinguished diffrently. The grouping of central office employees can be divided into: employees, functionaries and structural officials. While grouping of branch office employees can be divided into: employees, functionaries, back office officials, and marketing officials (individual and group insurance divisions). Each criterion is defined in scale of values as follows: 95-100; 8094; 60-79; 40-59, and each scale given descriptive explanation. There are four (4) dimensions used in the assessment of employee performance, there are: (1) Achieving Target, (2) Technical and Administration Capability, (3) Professional and Personality Factors, and (4) Managerial Capabilities Factors.

Methods of performance assessment in AJB Bumiputera 1912 conducted by using 180-degree feedback, assessments done from superiors to subordinates, and to validate the results of the 
assessment carried out further appraisal by superiors direct from the evaluator itself. Broadly speaking, the performance appraisal process in AJB Bumuputera 1912 can be seen in the following figure:

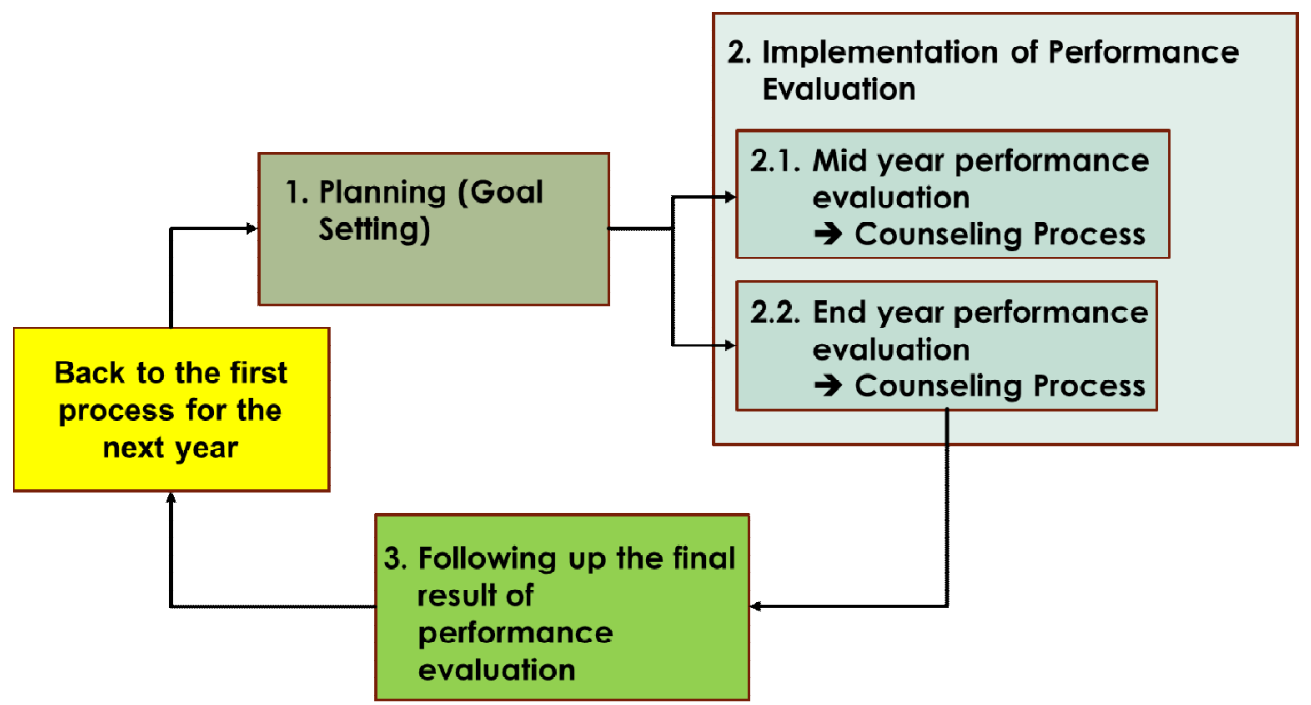

Figure 1. Process Flow of Performance Evaluation in AJB Bumiputera 1912..

In general, the evaluation is an assessment of the implementation of a program that has been carried out and that will be used to predict, calculate, and control the execution of the program so that implementation of the program in the future is much better. According to Naihasy (2006), the evaluation in terms of more specific, is concerns the production of information about the value or benefit of a policy. When the result of the policy turned out to have value, then these results contribute to the goals and objectives. It can be said that the policy or program has achieved a meaningful level of performance, which means that the policy issues made clear or overcome. Meanwhile, according to Nugroho (2009), the evaluation is necessary to look at the gap between hope and reality.

Evaluation program is a systematic method to collect, analyze, and use information to answer the basic questions about the program. According to Arikunto and Abdul Jabar (2008) evaluation of the program is an attempt to know the implementation of a policy. Evaluation can be used to check the rate of success of the program relating to the environment of the program with a judgment whether the program is passed, delayed, improved, developed, accepted, or rejected.

\section{PURPOSE}

Based on the these problems mapping, the focus of this study was to evaluate the gap in the implementation of employee performance management in AJB Bumiputera 1912 that compared with existing designs and ideal design (according to the needs of companies today). As for the subfocus of this research are: (1) The quality and validity of the design of performance management if it is aligned with the goals and needs of today's organizations, the vision, mission, values, business processes, structure of employment, job description, the system of human resource management in AJB Bumiputera 1912, (2) the effectiveness of the installation and the availability of supporting infrastructure to facilitate the implementation of the performance management of employees in AJB Bumiputera 1912, (3) the effectiveness of the implementation of the design management of employee performance in AJB Bumiputera 1912 when compared with the set design, as well as when compared to the design performance management ideal (according to the needs of companies 
at the moment), and (4) correspondence between the results of the implementation of performance management with the expected results of the design of existing performance management and performance management design ideal.

\section{RESEARCH METHODS}

This study uses the method of evaluation, with qualitative approach supported by statistical data as scientific methods to analyze the data that is intended to look at the effectiveness of employee performance management implementations in AJB Bumiputera 1912. The selected evaluation model is a DEM model of Malcolm Provus with four components of the evaluation, design evaluation, installation evaluation, implementation evaluation, and outcome evaluation.

Data were collected through questionnaires, the study of documents, interviews, and observations, which are classified as primary data and secondary data. Qualitative data analysis is done through a phase of data reduction, data presentation stage and the stage of conclusion. Quantitative data were processed using simple statistics with weight and percentage value.

The reason for choosing DEM to evaluate the implementation of performance management in AJB Bumiputera 1912 because DEM evaluation includes evaluation of the design, installation, implementation, and results that are highly suitable for evaluating employee performance management. In this study, the evaluation of the design is to evaluate employee performance management design, installation evaluate means of support and socialization of design performance management, including planning performance. Evaluation of the implementation of performance management is evaluating the implementation stage of the target setting, managing and performance reviews.Evaluation of the outcome isevaluating the results of intermediate and final outcome of performance management, including rewarding performance. DEM evaluation stages can be seen in the image below:
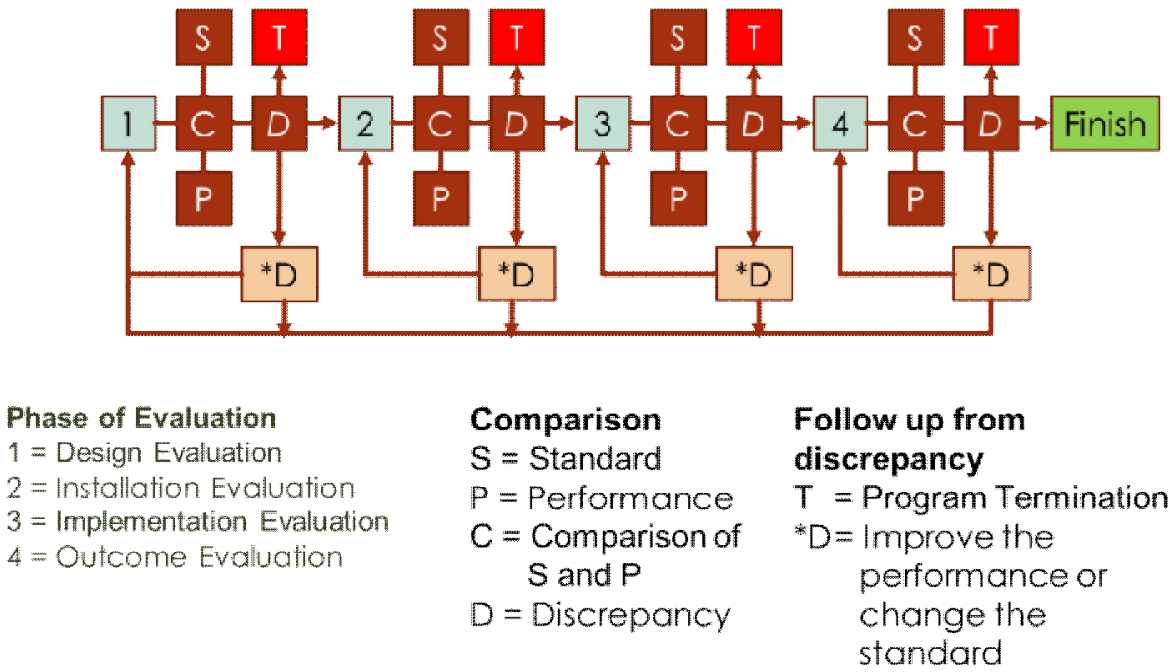

Figure 2. Stages of Evaluation Process in Evaluation Method Using DEM.

DEM can be seen as an SPD cycle, there are: (1) Set the Standards; (2)

Performance Measurement; (3) Discrepancy Measurement; (4) Decision-making; (5) Decreases the value Discrepancy; (6) Return to the first step evaluation. Based on the flow in Figure 2, can be explained that at each stage of the evaluation, from the evaluation of the design, installation, 
implementation, and outcome always do a comparative analysis between Standard (S) and Performance $(\mathrm{P})$, which results in a value of Discrepancy (D).

The data source of this research are parties related to performance management in AJB Bumiputera 1912, including the Director of Human Resources, Head of Department (Human Resources, Corporate Planning, Finance, Marketing Division, Corporate Communications), Assistant Director of Human Resources, Tim Taskforce HR, representative leaders and staff from several units, expert who understand the concepts and implementation of performance management.

The collected data will be grouped based on information obtained through interviews, document study and observation. Grouped data presented as qualitatively and/or quantitatively. Qualitative data will be considered to describe information based on theoretical basis and legality basis. Quantitative data were processed using simple statistical analysis so that the average value used to see the tendency of the data. Results of the assessment evaluation of the program are classified into four components, design evaluation, input evaluation, process evaluation and outcome evaluation.

\section{RESULT AND DISCUSSION}

Referring to the DEM evaluation model, it is necessary to assign values of Standard (S), Performance (P), and Discrepancy (D). Standard conditions that were used to analyze the data from the questionnaire is the highest score (5), questionnaire was designed using a Likert scale of 1 to 5. Performance $(\mathrm{P})$ is the score of the selected answer from respondents to each question on the questionnaire. While Discrepancy (D) is a gap, the difference between the Standard and Performance.

The Standard that were used to analyze the discrepancy from the interview and studyof the documents are ideal conditions according to expert HR consultant ${ }^{\text {ee }}$ sopinion, reference books, or determined by agreement between the decision makers in AJB Bumiputera 1912 and researchers. How to analyze the gaps is to compare standard conditions with actual conditions.

\section{Design Evaluation of Employee Performance Management}

Evaluation of design of employee performance management in AJB Bumiputera 1912 aims to evaluate the suitability of the design of employee performance management with the company"s needs and goals, vision, mission, and values at this time. The aspects that evaluated on design components are: (1) basic policy and legal basis of performance management, (2) the purpose of of performance management, (3) human resources involved and their role, (4) the execution time of performance evaluation, (5) scope of performance management, (6) performance assessment criteria, (7) the method of performance appraisal, and (8) phases of performance management.

In the results of the gap analysis in the design phase of the evaluation, there are several aspects in the design of employee performance management in AJB Bumiputera 1912 that there is no discrepancy because some of the design aspects of performance management has been described in the decree of directors. These results are presented in Table 1.

Table 1. Design Evaluation Analysis which did not have Discrepancy

\begin{tabular}{l|l|l} 
Aspect & Reason & Recomendation \\
\hline
\end{tabular}




\begin{tabular}{|c|c|c|}
\hline $\begin{array}{l}\text { 1. Basic policy and } \\
\text { legal basis of } \\
\text { performance } \\
\text { management. }\end{array}$ & $\begin{array}{l}\text { There are legal basis for } \\
\text { employee performance } \\
\text { management in form of: PKB, } \\
\text { SK.22 / DIRPEL / } \\
\text { 94., and PE } 18 \text { / DIRPEL / }\end{array}$ & $\begin{array}{l}\text { Although it has been set, but it needs to be } \\
\text { reviewed to suit the } \\
\text { needs and objectives of the company today }\end{array}$ \\
\hline $\begin{array}{l}\text { 2.Human } \\
\text { resources involved } \\
\text { and their role. }\end{array}$ & $\begin{array}{l}\text { Has arranged for anyone } \\
\text { involved, in the performance } \\
\text { assessment manual and SK. } 22 \text { / } \\
\text { DIRPEL / } 94\end{array}$ & $\begin{array}{l}\text { Although it has been set, but it needs to be } \\
\text { reviewed about SK Careers Committee and } \\
\text { outlined their duties and responsibilities, so } \\
\text { that in the future Careers Committee can } \\
\text { give recommendations in employee } \\
\text { performance evaluation and also conduct } \\
\text { succession planning. }\end{array}$ \\
\hline $\begin{array}{l}\text { 3.The timing of the } \\
\text { performance } \\
\text { evaluation. }\end{array}$ & $\begin{array}{l}\text { In the manual books scheduled } \\
\text { for July and December. }\end{array}$ & - \\
\hline $\begin{array}{l}\text { 4.Scope of } \\
\text { performance } \\
\text { management. }\end{array}$ & $\begin{array}{l}\text { Provided clear information } \\
\text { about who is to be assessed and } \\
\text { who was the assessor, and the } \\
\text { weight of mark at each job } \\
\text { level. }\end{array}$ & - \\
\hline $\begin{array}{l}\text { 5.The method of } \\
\text { performance } \\
\text { evaluation. }\end{array}$ & $\begin{array}{l}\text { The performance } \\
\text { evaluation is applied } \\
\text { using } 180^{\circ} \text { assessment } \\
\text { methods. }\end{array}$ & $\begin{array}{l}\text { Although the method has been established, } \\
\text { but is necessary to review the objective } \\
\text { assessment methods, eg } 360^{\circ} \text { assessment } \\
\text { methods. }\end{array}$ \\
\hline
\end{tabular}

Some discrepancy from the results of the gap analysis in the design phase of the evaluation, can be seen in Table 2.

Table2. Discrepancy Analysis on Design Evaluation of Employee Performance Management

\section{Discrepancy}

\section{Causative Factor}

Alternative Solution 


\begin{tabular}{|c|c|c|}
\hline $\begin{array}{l}\text { D1. Understanding of } \\
\text { the entire } \\
\text { organization } \\
\text { members to the } \\
\text { vision, mission, } \\
\text { values }(\mathrm{V}, \mathrm{M}, \mathrm{V}) \text {. }\end{array}$ & $\begin{array}{l}\text { Lack of socialization on the } \\
\text { vision, mission, values. }\end{array}$ & $\begin{array}{l}\text { Created an sustainable socialization and } \\
\text { internalization of } \mathrm{V}, \mathrm{M}, \mathrm{V} \text { to all members } \\
\text { of the organization as well as the } \\
\text { monitoring system. }\end{array}$ \\
\hline $\begin{array}{l}\text { D2. The alignment of } \\
\text { performance } \\
\text { management with } \mathrm{V} \text {, } \\
\mathrm{M}, \mathrm{V} \text {. }\end{array}$ & $\begin{array}{l}\text { Vision, Mission, Values not } \\
\text { yet translated into a technical } \\
\text { manual and behavioral } \\
\text { indicators. }\end{array}$ & $\begin{array}{l}\text { - Outlines the vision, mission, values } \\
\text { become the strategic objective in } \\
\text { function unit / department / division / } \\
\text { region. } \\
\text { - Elaboration of strategic objectives } \\
\text { become teamunit targets and individual } \\
\text { targets. } \\
\text { - Elaborate the vision, mission, values } \\
\text { into behavioral indicators that are easily } \\
\text { understood and implemented. } \\
\text { - Elaboration of behavioral } \\
\text { indicatorsstandard into a core } \\
\text { competency. }\end{array}$ \\
\hline $\begin{array}{l}\text { D3. The alignment of } \\
\text { performance } \\
\text { management with } \\
\text { HR management } \\
\text { and organizational } \\
\text { culture }\end{array}$ & $\begin{array}{l}\text { There is no HRM blueprint } \\
\text { that integrated with the } \\
\text { vision, mission, values and } \\
\text { business strategy. } \\
\text { - Lack of commitment and } \\
\text { direction of BOD, frequent } \\
\text { change of directors in a } \\
\text { short period of time. }\end{array}$ & $\begin{array}{l}\text { - It needs to make competencybased } \\
\text { HRM Blueprint using the Balanced } \\
\text { Scorecard approach, incorporating KPI } \\
\text { based performance management and } \\
\text { competency. } \\
\text { - BOD commitmentsare necessary to } \\
\text { mobilize the whole unit leader to run a } \\
\text { competency-based HR management. } \\
\text { - Each unit perform a SWOT analysis and } \\
\text { design strategies function in their work } \\
\text { unit, so it can be described clearly about } \\
\text { strategic objectives, business processes, } \\
\text { as well as updating the } \\
\text { regulationsthatare needed. }\end{array}$ \\
\hline \multirow[t]{2}{*}{ D iscrepancy } & Causative Factor & Alternative Solution \\
\hline & & $\begin{array}{l}\text { DIncreasing competence of strategic } \\
\text { planning for the top managers. }\end{array}$ \\
\hline
\end{tabular}




\begin{tabular}{|c|c|c|}
\hline $\begin{array}{l}\text { D4. Model and flowsof } \\
\text { performance } \\
\text { management } \\
\text { processes. }\end{array}$ & $\begin{array}{l}\text { Design performance } \\
\text { management is currently } \\
\text { only in the form of SK and } \\
\text { PE as well as the technical } \\
\text { guidelines for assessing } \\
\text { employee performance. } \\
\text { - Not adjusted to the current } \\
\text { regulatory needs. }\end{array}$ & $\begin{array}{l}\text { Make employee performance } \\
\text { management model that is aligned with } \\
\text { the vision, mission, values, strategy, } \\
\text { organizational } \\
\text { design, as well as models of } \\
\text { competency-based HR management. } \\
\text { Create a systematic and clear flow } \\
\text { phases of performance management and } \\
\text { and create a technical guide book. }\end{array}$ \\
\hline $\begin{array}{l}\text { D5. Clarity of duty, } \\
\text { responsibility at } \\
\text { every level } \\
\text { positions. } \\
\text { D6. The clarity of the } \\
\text { unit target and the } \\
\text { individual target, } \\
\text { mainly in back } \\
\text { office }\end{array}$ & $\begin{array}{l}\text { - Job description is not } \\
\text { detailed at all levels } \\
\text { positions } \\
\text { - No key result areas and } \\
\text { standards of competence at } \\
\text { each position }\end{array}$ & $\begin{array}{l}\text { - Job description as a contract of } \\
\text { employment of each employee, need to } \\
\text { be equipped with the key result areas } \\
\text { and clear individual and team targets. } \\
\text { - Create a standard of competence for } \\
\text { each position from the highest position } \\
\text { to the lowest positions. }\end{array}$ \\
\hline $\begin{array}{l}\text { D7. Clarity of employee } \\
\text { performance } \\
\text { evaluation criteria. }\end{array}$ & $\begin{array}{l}\text { पThe performance } \\
\text { evaluation criteria for of a } \\
\text { behavioral description is } \\
\text { quantified, but it is still } \\
\text { common. }\end{array}$ & $\begin{array}{l}\text { - Unit leader elaborate function strategic } \\
\text { goals intoteam KPI and individual KPI } \\
\text { for officer in his/her unit. } \\
\text { - Need standard of competence at every } \\
\text { job level. }\end{array}$ \\
\hline
\end{tabular}

\section{Installation Evaluation of Employee Performance Management}

Evaluation of installation of employee performance management in AJB Bumiputera 1912 aimed to evaluate the completeness of the support for the implementation of performance management. The aspects that evaluated on installation components are: (1) guidance, performance management procedures, (2) precondition and the availability of human resources involved, and (3) the availability of systems and means of supporting the implementation of performance management.

The results of the gap analysis of the evaluation installationsphase, there are some discrepancies because the reference that available are only in the form of SK and performance assessment guide books. The results of the analysis of the discrepancies can be seen in Table 3 below:

Table 3. Discrepancy Analysis on Installation Evaluation of Employee Performance Management

\begin{tabular}{l|l|l} 
Discrepancy & Causative Factor & Alternative Solution
\end{tabular}




\begin{tabular}{|c|c|c|}
\hline $\begin{array}{l}\text { D1. An understanding of all } \\
\text { employees on } \\
\text { performance } \\
\text { management. }\end{array}$ & $\begin{array}{l}\text { - Understanding of the } \\
\text { organization's members on } \\
\text { performance management is } \\
\text { not same. } \\
\text { - Commitment and } \\
\text { direction of BOD is still } \\
\text { lacking, because of frequent } \\
\text { change of directors in a short } \\
\text { period of time. }\end{array}$ & $\begin{array}{l}\text { - Performance management } \\
\text { socialization with attractive } \\
\text { appearance and performed } \\
\text { continuously. } \\
\text { - Socialization starts from BOD to } \\
\text { bottom (top-down). } \\
\text { - Conduct an evaluationto measure } \\
\text { the level of understanding of the } \\
\text { performance management. }\end{array}$ \\
\hline $\begin{array}{l}\text { D2. Availability of } \\
\text { technical guidelines on } \\
\text { performance } \\
\text { management phases. } \\
\text { D3. Availability of } \\
\text { guidelines of } \\
\text { Coaching \& } \\
\text { Counseling. } \\
\text { D4. Top-down } \\
\text { socialization of } \\
\text { performance } \\
\text { management. }\end{array}$ & $\begin{array}{l}\text { - Unit leader is less responsive } \\
\text { to the availability of } \\
\text { performance management } \\
\text { guidelines and guidance } \\
\text { counseling. } \\
\text { - Uneven understanding of } \\
\text { performance management, } \\
\text { counseling and coaching. } \\
\text { - There are some resistances to } \\
\text { accept new things or to } \\
\text { change. } \\
\text { - Directors often replaced }\end{array}$ & $\begin{array}{l}\text { - Making the technical guidelines } \\
\text { that is easily understood by all } \\
\text { members of the organization. } \\
\text { - Continuous training and } \\
\text { development of performance } \\
\text { management. } \\
\text { - Return the term of office of } \\
\text { directors to } 5 \text { (five) years, so that } \\
\text { he/she can run the continuity of the } \\
\text { program completely. }\end{array}$ \\
\hline
\end{tabular}

\begin{tabular}{|l|l|l}
\hline Discrepancy & \multicolumn{1}{|c|}{ Causative Factor } & Alternative Solution \\
\hline $\begin{array}{l}\text { in a short period of time, } \\
\text { thereby disrupting the } \\
\text { continuity of a progarm. }\end{array}$ & \\
\hline
\end{tabular}




\begin{tabular}{|c|c|c|}
\hline $\begin{array}{l}\text { D5. Availability of tools } \\
\text { that support the } \\
\text { implementation of } \\
\text { performance } \\
\text { management. }\end{array}$ & $\begin{array}{l}\text { IT is not yet fully integrated, } \\
\text { resulting in the risk of error } \\
\text { and subjectivity performance } \\
\text { reports. } \\
\text { - Monitoring performance is still } \\
\text { done manually and paper } \\
\text { based. } \\
\text { - There is no system for } \\
\text { monitoring the work regularly. }\end{array}$ & $\begin{array}{l}\text { - Built an integrated IT system as a } \\
\text { means to manage corporate } \\
\text { performance, unit / team, and } \\
\text { individuals that inline with the } \\
\text { strategic objectives. } \\
\text { - Once KPI and competency based } \\
\text { performance management built, } \\
\text { then it can be integrated with an } \\
\text { online system to view the } \\
\text { dashboard of team and individual } \\
\text { performance. } \\
\text { - Develop career paths, the talent } \\
\text { pool, succession planning, and } \\
\text { human resources management } \\
\text { based on competence and IT, } \\
\text { towards high performancehuman } \\
\text { resources. }\end{array}$ \\
\hline $\begin{array}{l}\text { D6. Availability of BOD } \\
\text { budget and } \\
\text { commitment to carry } \\
\text { out every strategic } \\
\text { policy. }\end{array}$ & $\begin{array}{l}\text { The budget required to } \\
\text { develop HRM systems } \\
\text { available but limited. } \\
\text { The program is not continuous } \\
\text { in the planning and } \\
\text { implementation because of the } \\
\text { change the board of directors } \\
\text { so that decisions are stalled. }\end{array}$ & $\begin{array}{l}\text { Requires the budget to be able to } \\
\text { design and execute an integrated } \\
\text { performance management } \\
\text { program, which can be allocated } \\
\text { from the cost of human resource } \\
\text { development which is } \\
\text { currently their implementation is } \\
\text { still less than } 5 \% \text { of personnel } \\
\text { costs. } \\
\text { - It need the commitment of BOD in } \\
\text { planning, socialization, } \\
\text { implementation and evaluation, } \\
\text { because this integrated program } \\
\text { will take approximately } 2 \text { years to } \\
\text { the reach the understandingof the } \\
\text { phase to and all members of the } \\
\text { organizationbecome committed to } \\
\text { it. }\end{array}$ \\
\hline
\end{tabular}

\section{Implementation Evaluation of Employee Performance Management}

Evaluation of implementations of employee performance management in AJB Bumiputera 1912 aimed at evaluating the scope, criteria, methods, phases / process and timing of implementation and compliance with the input-process-output on the design of performance management and performance appraisal guidelines that were used, compared with the current implementation.

Gaps analysis in the implementation phase of the evaluation is to describe the results of an evaluation of the target planning, monitoring and evaluation, as well as feedback, can be seen in Table 4 below: 
Table4. Discrepancy Analysis on Implementation Evaluation of Employee Performance Management

\begin{tabular}{|c|c|c|}
\hline D iscrepancy & Causative Factor & Alternative Solution \\
\hline $\begin{array}{l}\text { D1. Establishing } \\
\text { performance targets. }\end{array}$ & $\begin{array}{l}\text { - Establishment of corporate } \\
\text { performance targets and work } \\
\text { units have been conducted each } \\
\text { year end at Rapimnas. } \\
\text { - Not translated into individual } \\
\text { targets except for sales. } \\
\text { - Drafting work programs and } \\
\text { budgets usually refers to program } \\
\text { and budget of the previous year. }\end{array}$ & $\begin{array}{l}\text { - The process of setting targets } \\
\text { should refer to the results of } \\
\text { cascading vision, mission, and } \\
\text { strategic corporate objectives } \\
\text { Corporate Scorecard. } \\
\text { - Corporate Scorecard } \\
\text { elaborated to function } \\
\text { scorecard in the work unit. } \\
\text { - Scorecard function revealed to } \\
\text { be smaller scorecard and } \\
\text { further into individual targets } \\
\text { which are equipped with } \\
\text { Individual Development Plan. }\end{array}$ \\
\hline
\end{tabular}

\begin{tabular}{|c|c|c|}
\hline Discrepancy & Causative Factor & Alternative Solution \\
\hline $\begin{array}{l}\text { D2. Performance } \\
\text { Monitoring }\end{array}$ & $\begin{array}{l}\text { - Monitoring of work programs and } \\
\text { budgets in thework unit has been } \\
\text { conducted every month by the } \\
\text { Department of Corporate Planning } \\
\text { and Finance Department. } \\
\text { - There are no individual } \\
\text { performance monitoring tools. } \\
\text { - There are business service system } \\
\text { (BIL) and HRIS but not yet well } \\
\text { integrated to monitor } \\
\text { performance. } \\
\text { - Administrative reporting is } \\
\text { manual, not yet integrated with } \\
\text { IT. }\end{array}$ & $\begin{array}{l}\text { - It should be supported by an } \\
\text { integrated IT between business } \\
\text { processes and employee } \\
\text { performance management. } \\
\text { - Leaders work units monitor and } \\
\text { evaluate performance regularly } \\
\text { and recorded, so the review of } \\
\text { performance can be done more } \\
\text { easily. }\end{array}$ \\
\hline $\begin{array}{l}\text { D3. Timely implementation } \\
\text { of performance } \\
\text { evaluation }\end{array}$ & $\begin{array}{l}\text { - Chairman of the work unit are } \\
\text { less responsive and less trying to } \\
\text { understand the regulations and } \\
\text { guide books of Performance } \\
\text { Management. } \\
\text { - Change the execution time of the } \\
\text { review performance from } 2 \mathrm{x} \mathrm{a} \\
\text { year to just once a year. }\end{array}$ & $\begin{array}{l}\text { - Socialization of regulations and } \\
\text { instructions related to } \\
\text { performance management that } \\
\text { is packaged in a } \\
\text { practical, easy to understand } \\
\text { and interesting way. } \\
\text { - Need reward and punishment to } \\
\text { someone who mantain the } \\
\text { timeliness of reporting the } \\
\text { results of the performance } \\
\text { evaluation. }\end{array}$ \\
\hline
\end{tabular}




\begin{tabular}{|c|c|c|}
\hline $\begin{array}{l}\text { D4. Implementation } \\
\text { Coaching \& } \\
\text { Counseling }\end{array}$ & $\begin{array}{l}\text { Socialization and coaching \& } \\
\text { counseling training has not been } \\
\text { decided as the program that is } \\
\text { important in the development of } \\
\text { employees. } \\
\text { - Not all the chairman of the unit } \\
\text { felt it is important to conduct } \\
\text { coaching and counseling when } \\
\text { doing performance reviews. }\end{array}$ & $\begin{array}{l}\text { - Need to create guidelines for } \\
\text { coaching and counseling. } \\
\text { Trainthe work unit leader about } \\
\text { coaching and counseling. } \\
\text { - Monitoring and evaluating the } \\
\text { implementation of coaching and } \\
\text { counseling. }\end{array}$ \\
\hline
\end{tabular}

D5. Objectivity of assessment
- Assessment of performance is considered routine, noncompliance assessment time was considered the norm.

- Lack of monitoring and evaluation of individual and team targets.

- Tend to generalize the outcome at grade $\mathrm{B}$.
- Team and individual performance targets needed to be clear.

- Supported by integratedIT for monitoring performance.

- 360-degree performance appraisal method.

- Implemented coaching and counseling when doing performance reviews, so they can devise corrective action plan.

- The firmness of reward and punishment.

- The results of performance assessment needs to be documented in an integrated HRIS system for the purpose of competency-based HR management.

- Completing an employee skills inventory that can be used for career planning, training \& development, succession planning and talent management. 
D7.Reward and punishment do not provide reinforcement effect
- Reward given according to the assessment results $\mathrm{A}, \mathrm{B}, \mathrm{C}$ in the form of rising around $5 \%$ of basic salary for one grade.

- Work unit leaders tend to "have a sense of pity" when giving punishment, so that the problem is returned to the HR Department.
- Reward in the form of base salary increases, should be reviewed to be incentive thatchallenging for talent and does not create a comfort zone for non-talent.

- Implementation of strict punishment if there are some strong supporting evidences found.

- Giving an exampleof reward and punishment that firmly and fairly given by supervisor.

- Enhancing the role and function of the working unitleaders in managing human resources in the unit.

\section{Outcome Evaluation of Employee Performance Management}

Evaluation of the outcome of employee performance management in AJB Bumiputera 1912 aims to evaluate the comparison between the results of employee performance management implementations derived from information based on the results of questionnaires, interviews, document study and observation, then compared with the goals or objectives of management performance and aligned with corporate goals.

Analysis of the gap at this stage of the evaluation are covering the intermediate results, i.e. the output of the management of employee performance itself, as well as the end result which is a goal (outcome) of the performance management of employees that have an impact on company performance, customer satisfaction, as well as the position and market share of companies in the industry.Discrepancy analysis in the outcome evaluationphase illustrated in Table 5 below:

Table5. Discrepancy Analysis on Outcome Evaluation of Employee Performance

Management

\begin{tabular}{|c|c|c|}
\hline D iscrepancy & Causative Factors & Alternative Solutions \\
\hline $\begin{array}{l}\text { INTERMEDIATE } \\
\text { RESULTS } \\
\text { D1. Implementation of the } \\
\text { results of performance } \\
\text { management has not } \\
\text { been able to } \\
\text { differentiate talents and } \\
\text { non-talents. }\end{array}$ & $\begin{array}{l}\text { - The results of performance } \\
\text { assessment are }>95 \% \text { were } \\
\text { grade B. } \\
\text { - The audit results are sometimes } \\
\text { still disputed between the } \\
\text { system factors or fraud, so } \\
\text { sometimes the punishment is } \\
\text { not strictly applied. }\end{array}$ & $\begin{array}{l}\text { - It is important of criteria and } \\
\text { performance targets are clear and } \\
\text { measurable. } \\
\text { - Repair system and IT that are } \\
\text { secure and integrated. } \\
\text { - The importance of early detection } \\
\text { and coaching program for the } \\
\text { prevention of errors and fraud. }\end{array}$ \\
\hline
\end{tabular}




\begin{tabular}{|c|c|c|}
\hline $\begin{array}{l}\text { D2. The outcome not used } \\
\text { optimally in the } \\
\text { placement, promotion } \\
\text { and demotion of } \\
\text { employees. }\end{array}$ & $\begin{array}{l}\text { - The results of the performance } \\
\text { appraisal are already taken into } \\
\text { consideration in the promotion, } \\
\text { but has not been taken into } \\
\text { consideration in the placement } \\
\text { and demotions. } \\
\text { - Recommendations are less } \\
\text { detailed to be able to map talent } \\
\text { and non-talent. }\end{array}$ & $\begin{array}{l}\text { - Setting the criteria and target that } \\
\text { measurable and integrated IT } \\
\text { support, so it can be mapped talent } \\
\text { and non-talent with Human Asset } \\
\text { Value (HAV) matrix, which maps } \\
\text { the performance vs. competence. } \\
\text { - Results of coaching and HAV } \\
\text { matrix can be used in designing } \\
\text { succession, individual plan, } \\
\text { competence development, } \\
\text { promotion, placement and } \\
\text { demotion of employees that can be } \\
\text { fairly measured. }\end{array}$ \\
\hline $\begin{array}{l}\text { D3. The outcome has not } \\
\text { been associated with the } \\
\text { development of } \\
\text { employee } \\
\text { competencies }\end{array}$ & $\begin{array}{l}\text { - Implementation of the results of } \\
\text { performance management has } \\
\text { not been able to provide } \\
\text { feedback on specific } \\
\text { competency gaps. } \\
\text { - The results of performance } \\
\text { assessment is still not been used } \\
\text { as a consideration of the } \\
\text { development of employee } \\
\text { competence. }\end{array}$ & $\begin{array}{l}\text { - Need to align the results of } \\
\text { coaching and counseling when } \\
\text { doing performance review with an } \\
\text { employee competence } \\
\text { developmentprogram. } \\
\text { - Supported by an integrated IT } \\
\text { system to facilitate the training } \\
\text { needs analysisfromthe results of } \\
\text { performance assessments. }\end{array}$ \\
\hline
\end{tabular}




\section{FIN AL RESULT}

D1. Work productivity
- IT has not been integrated so it causing more HR needs.

- Standard salary is still less competitive with competitors that affect the quality of recruitment and productivity.

- Performance management and human resources management system is not integrated with the vision, mission, values and strategic objectives that are supported by monitoring and evaluation system that produces valid and real time performance data.
- Performance management needs to be aligned and integrated with other HR management systems so it can improve employee motivation and productivity.

- HR management needs to be integrated with business strategy and the design of organization that integrated with IT-supporso it was able to create a high performance culture, with a fair reward and punishment.

- Need to conduct regular surveys to get feedback related to work productivity, job satisfaction, customer satisfaction, thereby improving performance management in the future.

\begin{tabular}{l|l|l}
\hline $\begin{array}{l}\text { D2. Linkage of } \\
\text { performance of } \\
\text { individuals, teams, and } \\
\text { organizations }\end{array}$ & $\begin{array}{l}\text { There are branch offices profit } \\
\text { and loss data, but it was not been } \\
\text { linked to the performance of } \\
\text { teams and individuals. } \\
\text { Declining of position in the } \\
\text { market share, and it is currently } \\
\text { at number 9. } \\
\text { Fat organizational structure, IT } \\
\text { has not fully }\end{array}$ & $\begin{array}{l}\text { Create a team and individual } \\
\text { performance measurement using } \\
\text { Balancedscore Card, consists of } \\
\text { these measurement perspective: } \\
\text { Financial, Customer, Internal } \\
\text { Business Processes, Learning and } \\
\text { Growth. } \\
\text { Clarifying the business }\end{array}$ \\
\hline Discrepancy & \multicolumn{1}{c}{ Causative Factors } & Alternative Solutions \\
\hline
\end{tabular}




\begin{tabular}{|c|c|c|}
\hline & $\begin{array}{l}\text { integrated, so that it less nimble } \\
\text { compared to a joint venture } \\
\text { competitor. } \\
\text { वPerformance management in } \\
\text { Bumiputera have not been } \\
\text { aligned and integrated with } \\
\text { other HR management systems. }\end{array}$ & $\begin{array}{l}\text { model, strategic objectives that } \\
\text { elaborated into human resource } \\
\text { management and integrated } \\
\text { performance management. } \\
\text { - Improve IT to become more secure } \\
\text { and integrated, so that it can be } \\
\text { simplifyingthe organizational } \\
\text { structure and human resource } \\
\text { needs } \\
\text { - Measurable Performance } \\
\text { Management and integrated with } \\
\text { other HR management, } \\
\text { creating talent and highperforming } \\
\text { human resources as the company's } \\
\text { competitiveness. }\end{array}$ \\
\hline $\begin{array}{l}\text { D3 Linkage of service } \\
\text { quality and performance } \\
\text { management. }\end{array}$ & $\begin{array}{l}\text { There is branch customer } \\
\text { satisfaction and complaints data, } \\
\text { but has not been linked to the } \\
\text { teams and individuals } \\
\text { performance. }\end{array}$ & $\begin{array}{l}\text { QCustomer servicesupported by } \\
\text { integratedIT, so Customer } \\
\text { Relationship Management (CRM) } \\
\text { can be built to improve customer } \\
\text { service. }\end{array}$ \\
\hline
\end{tabular}

\section{CONCLUSION}

Human capital is a capital that determines competitive advantage and success in achieving organizational goals. To achieve a competitive advantage through the practices of human resource management requires time and a process, which begins with managing employee performance objectively in order to generate motivation and high-performance culture. The objectivity of performance assessments will give effect to employee motivation, and will support the implementation of the management of high-performanceand high-commitmentorganizations.

Performance management is the management style in managing human resources that oriented to performance by doing the process of target setting, monitoring, and evaluation through the approach of open and sustainable communication in line with the vision, mission, values and strategic approach of companies as the driving force to achieve organizational goals.

The performance assessment is basically a key factor in order to develop an effective and efficient organization, because the results will be taken into consideration to establish a policy or program that is better on the human resources that exist within the organization.

In general, the results of the evaluation of the implementation of the performance management of employees in AJB Bumiputera 1912,there are some discrepanciesin implementation that are not in accordance with the standards established or less relevant to the demands of the current company needs. Therefore, it is necessary to make adjustment from the aspects of design, installation, implementation and empowerment of employee performance management results that integrated with other HR management systems. 
The results of this study are expected to be taken into consideration in the decision to implement the performance management in AJB Bumiputera 1912, because since 1994 until now it has never been evaluated. The HR department has been working with a consultant in 2014 to build a HR Management Blueprint for the company, but until now it has not been implemented yet.

The results of this study can be considered for an appropriate rapid decisionmaking for management in AJB Bumiputera 1912, especially to win the competition through an integrated HR management.

It is importantto do further research on the application of the Balanced Scorecard to manage the business consisting of these dimensions: financial, customer, internal business processes, and learning and growth. Furthermore, the business scorecard associated with the HR Scorecard, which is the measurement in human resource management that consists of 4 (four) roles: as an expert administration, strategic partner, change management, and individual contribution. For connect both of the scorecard, can be built workforce planning through an integrated performance management system.

\section{BIBLIOGRAPHY}

Arikunto, Suharsimi dan Cepi S. Abdul Jabar. Evaluasi Program Pendidikan: Pedoman Teoretis Praktis Bagi M ahasiswa dan Praktisi Pendidikan. edisi kedua. Jakarta: Bumi Aksara, 2008.

Armstrong, Michael. Amstrong's Handbook of Human Reource Management Practice. Philadelphia: Kogan Page, 2009.

Ivancevich, John M. H uman Resource M anagement. 10th edition. NewYork: McGrawHill/Irwin, 2007.

Naihasy, Syahrin. Kebijakan Publik - M enggapai M asyarakat M adani. Yogyakarta: Mida Pustaka, 2006.

Noe, Raymond A., et al. M anajemen Sumber Daya M anusia: $M$ encapai Keunggulan Bersaing terjemahan Didik Prayitno. Jakarta: Salemba Empat, 2011.

Nugroho, Riant. Public Policy. Jakarta: PT. Elex Media Komputindo, 2009. 